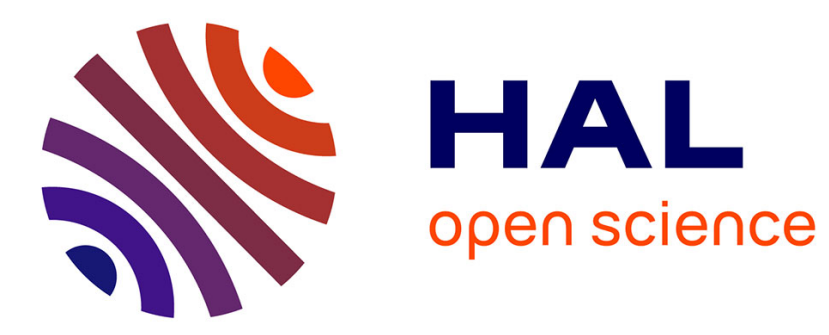

\title{
Fracture propagation during impact in three types of ceramics
}

\author{
E. Strassburger, H. Senf, H. Rothenhäusler
}

\section{To cite this version:}

E. Strassburger, H. Senf, H. Rothenhäusler. Fracture propagation during impact in three types of ceramics. Journal de Physique IV Proceedings, 1994, 04 (C8), pp.C8-653-C8-658. 10.1051/jp4:1994899 . jpa-00253460

\section{HAL Id: jpa-00253460 https://hal.science/jpa-00253460}

Submitted on 1 Jan 1994

HAL is a multi-disciplinary open access archive for the deposit and dissemination of scientific research documents, whether they are published or not. The documents may come from teaching and research institutions in France or abroad, or from public or private research centers.
L'archive ouverte pluridisciplinaire HAL, est destinée au dépôt et à la diffusion de documents scientifiques de niveau recherche, publiés ou non, émanant des établissements d'enseignement et de recherche français ou étrangers, des laboratoires publics ou privés. 


\title{
Fracture propagation during impact in three types of ceramics
}

\author{
E. Strassburger, H. Senf and H. Rothenhäusler
}

Fraunhofer-Institut für Kurzzeitdynämik, Ernst-Mach-Institut, Hauptstrasse 18, 79576 Weil am Rhein, Germany

\begin{abstract}
Plates of $\mathrm{SiC}, \mathrm{TiB}_{2}$ and $\mathrm{Al}_{2} \mathrm{O}_{3}$ were impacted edge-on with steel projectiles at striking velocities between $20 \mathrm{~m} / \mathrm{s}$ and $1000 \mathrm{~m} / \mathrm{s}$. Fracture propagation in the specimen was visualised by means of a Cranz-Schardin camera within the first twenty microseconds. The phenomenology of damage is discussed and compared for the different types of ceramics. The velocities of single cracks and crack fronts were measured. The experiments were supplemented by ceramographical investigations of recovered fragments. Void nucleation and coalescence could be identified as the failure mechanism in impacted $\mathrm{TiB}_{2}$.
\end{abstract}

Résumé - Les bords de plaques de $\mathrm{SiC}$, $\mathrm{TiB}_{2}$ et $\mathrm{Al}_{2} \mathrm{O}_{3}$ furent soumis à l'impact de projectiles d'acier à une vitesse d'impact entre $20 \mathrm{~m} / \mathrm{s}$ et $1000 \mathrm{~m} / \mathrm{s}$. La propagation des fissures dans les spécimens a été visualisée par moyen d'une caméra Cranz-Schardin pendant les premières 20 $\mu$ s après l'impact. La phénomènologie des dégâts est discutée et la comparaison a été faite entre les différents types de céramique. La vitesse des fissures simples et des fronts de fissures a été mesurée. Les essays furent complémentés par l'analyse céramographique d'éclats retrouvés. La nucléation de vides et la coalescence ont pu être identifiées comme mechanismes de défaillance dans le $\mathrm{TiB}_{2}$ soumis à l'impact.

\section{INTRODUCTION}

The interest in ceramic materials for armour applications has increased during the last two decades because it was and still is necessary to reduce the weight of armours for vehicles and in particular for aircrafts. Testing methods have been developed to establish a ballistic performance ranking of the different armour ceramics [1,2], and many composite armours exist which are designed to defeat specific threats. But testing the performance of structures mostly does not reveal the mechanisms that determine the protective strength because of the large number of geometric and material parameters. In most of the experimental techniques used in terminal ballistics the important quantities (e. g., depth of penetration, residual velocity) are determined after the penetration process is finished. However, earlier impact experiments with glass and ceramics [3,4] demonstrated that the destruction of these materials starts together with the propagation of the stress waves. The aim of the investigations reported here was to visualise the damage processes during impact in order to study how the material fails and is comminuted to achieve a deeper understanding of the mechanisms which determine the ballistic performance. Particularly the damage phenomenology is considered and the propagation velocities of different types of fracture are analysed. 


\section{EXPERIMENTAL SET-UP}

Figure 1 shows the experimental set-up schematically. The specimen were impacted edge-on. Fracture propagation was observed by means of a Cranz-Schardin camera during the first $20 \mu \mathrm{s}$ after impact. In order to visualise the cracks the surface of the ceramic specimen has to be polished mirror-like. Otherwise the intensity of the reflected light would not be sufficient to observe details on the surface of the specimen. With the $\mathrm{Al}_{2} \mathrm{O}_{3}$ - specimens a mirror-like surface cannot be reached. Therefore, they were coated with a thin layer of silver or aluminium.

\section{MATERIAL PROPERTIES}

Three types of ceramics were tested: "PAD" - SiC-B (PAD = Pressure Assisted Densified) and "PAD" - $\mathrm{TiB}_{2}$ from CERCOM Company and the CeramTech A $1898 \mathrm{Al}_{2} \mathrm{O}_{3}$ from HOECHST Company. Physical and mechanical properties of the ceramics as given by the manufacturer are listed in Table 1 .

Table 1. Physical and mechanical properties of the ceramics

\begin{tabular}{|l|c|c|c|}
\hline Material & $\mathrm{SiC}$ & $\mathrm{TiB}_{2}$ & $\mathrm{Al}_{2} \mathrm{O}_{3}(98 \%)$ \\
\hline Density $\rho\left[\mathrm{g} / \mathrm{cm}^{3}\right.$ ] & 3.18 & 4.43 & 3.79 \\
Young's Modulus [GPa] & 427 & 537 & 360 \\
Compressive Strength [GPa] & 3.41 & 4.82 & 4 \\
Bulk Modulus [GPa] & 223 & 233 & --- \\
Shear Modulus [GPa] & 195 & 249 & --- \\
Poisson's Ratio & 0.14 & 0.11 & --- \\
$\mathrm{c}_{\mathrm{L}}[\mathrm{m} / \mathrm{s}$ ] & 12250 & 11285 & 10440 \\
$\mathrm{c}_{\mathrm{T}}[\mathrm{m} / \mathrm{s}]$ & 7765 & 7431 & --- \\
\hline
\end{tabular}

The structure of the three types of ceramics is very different which can be recognised from the three micrographs shown in Figure 2. The $\mathrm{SiC}$ is a very fine grained material with an average grain size of $2 \mu \mathrm{m}$, whereas the average grain size in the alumina is $9 \mu \mathrm{m}$. The maximum grain length observed with these two ceramics is about $30 \mu \mathrm{m}$. Much bigger differences in the size of the grains occur in the $\mathrm{TiB}_{2}$, where the dimensions of the smallest grains are a few micrometers and the largest grains attain lengths of about $180 \mu \mathrm{m}$. However, the most important feature of this material is, that it exhibits cracks already in the initial state. These cracks predominantly occur along the boundaries of the large grains or they cleave large grains over their full length.

\section{EXPERIMENTAL RESULTS}

In order to be able to directly compare the damage of the different types of ceramics and the damage at different impact velocities, all the experiments were conducted with the same impact geometry. Blunt steel cylinders of $30 \mathrm{~mm}$ diameter and $23 \mathrm{~mm}$ length were shot against the specimens of the dimensions $100 \mathrm{~mm} \times 100 \mathrm{~mm} \times 10 \mathrm{~mm}$. The impact velocity was varied within the range from $20 \mathrm{~m} / \mathrm{s}$ to $1000 \mathrm{~m} / \mathrm{s}$.

\subsection{Damage Phenomenology}

Figure $3 a$ and $b$ show schematically the types of fractures that were observed. The designations for the different types of fracture were chosen analogous to the designations of the fracture types in glass [5]. In most cases the cone cracks could be identified first on the high-speed photographs. They start from the impact site of the edge of the projectile. The cracks that are generated in the region between the cone cracks are called primary cracks. In opposition to the fracture propagation observed in glasses, the primary fractures in ceramics do not appear as fine dark lines which grow continuously from the impact site. In most cases the edges and tips of the primary cracks are fuzzy. Branching of the cracks occurs frequently. Some of the cracks look like branches of a fir-tree (type 1, Fig. 3a), others seem to 
consist of many, successively formed short cracks which include a small angle with the main direction of fracture propagation (type 2, Fig. 3a). Two photographs of SiC specimens which exhibit the different types of cracks are shown in Figure 4. Primary cracks with sharp edges are observed rarely. But it has also been observed that a crack with sharp edges suddenly turns into a crack of type 1 or 2 . At striking velocities $\leq 85 \mathrm{~m} / \mathrm{s}$ the specimens could be rebuilt from the recovered fragments. An inspection of the crack surfaces revealed, that the crack surfaces are smooth when the edges are sharp. Cracks that appear fuzzy on the polished surface of the specimen have rough crack surfaces.

Similar to the fracture patterns found with glasses, wedge-shaped fracture zones can be recognised above the upper and below the lower cone crack. These secondary cracks always reveal sharp edges. This type of crack occurred most clearly with $\mathrm{SiC}$ at a striking velocity of $185 \mathrm{~m} / \mathrm{s}$, which can be seen from the photograph $(5 \mu \mathrm{s}$ after impact) shown in Figure $4 \mathrm{~b}$.

With the $\mathrm{TiB}_{2}$ specimen cracks of the types 1 and 2 can hardly be observed. Already at low loadings a fracture front forms between the cone cracks that consists of many short cracks. This fracture pattern is drawn schematically in Figure $3 \mathrm{~b}$. The photograph of a $\mathrm{TiB}_{2}$ plate $4 \mu \mathrm{s}$ after impact at $85 \mathrm{~m} / \mathrm{s}$ illustrates this type of damage (Fig. 5). The fracture patterns observed with the $\mathrm{Al}_{2} \mathrm{O}_{3}$ ceramics are similar to those in the $\mathrm{SiC}$. Figure 6 shows an $\mathrm{Al}_{2} \mathrm{O}_{3}$ specimen $9.8 \mu \mathrm{s}$ after impact at $85 \mathrm{~m} / \mathrm{s}$. At impact velocities in the range $350 \mathrm{~m} / \mathrm{s} \leq \mathrm{v}_{\mathrm{p}} \leq 600 \mathrm{~m} / \mathrm{s}$ the fracture patterns of $\mathrm{SiC}$ and $\mathrm{TiB}_{2}$ are similar. This is demonstrated by the photographs of a SiC specimen $\left(\mathrm{v}_{\mathrm{P}}=513 \mathrm{~m} / \mathrm{s}, 4.7 \mu \mathrm{s}\right.$ after impact) and a $\mathrm{TiB}_{2}$ specimen $\left(\mathrm{v}_{\mathrm{P}}=560 \mathrm{~m} / \mathrm{s}, 4.7 \mu \mathrm{s}\right.$ after impact) in Figure 7 . In both cases a dense field of fuzzy cracks grows into the specimen. The density of the crack field decreases with increasing time of propagation. The fracture patterns observed with $\mathrm{SiC}$ and $\mathrm{Al}_{2} \mathrm{O}_{3}$ at impact velocities between $600 \mathrm{~m} / \mathrm{s}$ and $1000 \mathrm{~m} / \mathrm{s}$ do not differ from those in the range $350 \mathrm{~m} / \mathrm{s} \leq \mathrm{v}_{\mathrm{P}} \leq 600 \mathrm{~m} / \mathrm{s}$.

A new damage phenomenon was found with $\mathrm{TiB}_{2}$ at impact velocities above $780 \mathrm{~m} / \mathrm{s}$. Figure 8 shows a. photograph of a $\mathrm{TiB}_{2}$ specimen, $6.2 \mu \mathrm{s}$ after the impact of the projectile at $784 \mathrm{~m} / \mathrm{s}$. The fracture front is preceded by a field of black dots on the surface of the specimen. Only few fragments of the specimen could be recovered, most of it was comminuted to very small particles. But an examination of the surfaces of the recovered fragments revealed many small pits where material was broken out. This is the only hint with respect to the origin of the black dots seen on the high-speed photographs.

\subsection{Analysis of Fracture Velocities}

Other than in glass, different types of cracks are generated and different fracture velocities are observed at one impact velocity in one specimen. Therefore, it is necessary to distinguish between the velocity of continuously growing cracks, including the secondary cracks with sharp edges, fuzzy crack traces and crack fronts. In the following the term damage velocity in ceramics always denotes the velocity of the fastest fracture which was observed. In Figures $9 \mathrm{a}, \mathrm{b}, \mathrm{c}$ the mean damage velocities $v_{p}$ observed with $\mathrm{SiC}, \mathrm{TiB}_{2}$ and $\mathrm{Al}_{2} \mathrm{O}_{3}$ are plotted versus the impact velocity $\mathrm{v}_{\mathrm{p}}$. In each of the ceramics $\mathrm{v}_{\mathrm{D}}$ increases with increasing striking velocity. The damage velocities approach the longitudinal wave velocity $c_{L}$ at high loadings. With $\mathrm{TiB}_{2}, \mathrm{v}_{\mathrm{D}}$ rises continuously and $\mathrm{c}_{\mathrm{L}}$ is gained when $\mathrm{v}_{\mathrm{P}}$ exceeds $780 \mathrm{~m} / \mathrm{s}$. SiC and $\mathrm{Al}_{2} \mathrm{O}_{3}$ exhibit a steep rise of $\mathrm{v}_{\mathrm{D}}$ in the range of striking velocities between $150 \mathrm{~m} / \mathrm{s}$ and $200 \mathrm{~m} / \mathrm{s}$. In the case of $\mathrm{SiC}$ this step corresponds to the transition in fracture type from single, distinguishable fuzzy crack traces to a crack front. Some of the SiC specimen exhibited secondary fracture zones very clearly. The fact that the secondary cracks form a triangle shows that they grow at the same speed. The analysis of velocities of all those secondary cracks whose tips could be observed on several photographs revealed crack velocities between $3000 \mathrm{~m} / \mathrm{s}$ and $4000 \mathrm{~m} / \mathrm{s}$ independent of the loading. The mean velocity of the secondary cracks is $3490 \mathrm{~m} / \mathrm{s} \pm 390 \mathrm{~m} / \mathrm{s}$. In four of our experiments the transversal wave generated at the impact could be observed. The mean of the measured velocities in $7255 \mathrm{~m} / \mathrm{s} \pm$ $140 \mathrm{~m} / \mathrm{s}$. The Rayleigh wave velocity $c_{R}$ is approximately $0.9 c_{T}$ from what follows $c_{T, S i C}=6530 \mathrm{~m} / \mathrm{s}$. The investigations of glasses [5] have shown that the secondary cracks propagate at terminal crack velocity $\mathrm{v}_{C}$, which is approximately half of the Rayleigh wave velocity with float glass and the optical glasses $\mathrm{K5}$ and $\mathrm{F} 6$. This is also correct with the secondary cracks in SiC: $\mathrm{v}_{\mathrm{C}, \mathrm{SiC}} \sim 0.5 \mathrm{c}_{\mathrm{R}}=3265 \mathrm{~m} / \mathrm{s}$. This analogy suggests that a terminal crack velocity exists for SiC. However, this velocity has been observed only with one of the various types of fracture. Therefore, it is important to distinguish between the different types of fracture whenever fracture velocities are considered.

\section{MICROSTRUCTURAL ANALYSIS}

Recovered fragments were sectioned in a direction perpendicular to the surfaces of the undamaged specimen. Micrographs of $\mathrm{TiB}_{2}$ specimen (impacted at $784 \mathrm{~m} / \mathrm{s}$ ) and a SiC specimen (impacted at 
$1040 \mathrm{~m} / \mathrm{s}$ ) are shown in Figure 10 . The most remarkable feature of the $\mathrm{TiB}_{2}$ fragment is that a lot of voids have been generated particularly at these points where three or more grains adjoin and in the interior of the large grains. Transcrystalline and intercrystalline fracture is observed. The micrograph shows that the cracks within the large grains as well as the intercrystalline cracks have been formed by coalescence of voids. The formation of voids has not been found with $\mathrm{SiC}$ as the micrograph in Figure 10 reveals. Cracks are mainly intercrystalline in this fine grained material.

\section{SUMMARY}

The fracture propagation was observed during impact in $\mathrm{SiC}$, $\mathrm{TiB}_{2}$ and $\mathrm{Al}_{2} \mathrm{O}_{3}$ by means of a CranzSchardin camera. The propagation velocities were determined for the different types of fracture. At very high loadings damage velocity reaches approximately the longitudinal wave velocity $c_{L}$ with all three materials. A terminal crack velocity was found for one type of fracture in SiC. Ceramographical investigations of recovered fragments revealed the failure mechanism in $\mathrm{TiB}_{2}$.

\section{Acknowledgement}

We thank Mr. D. Preuß, Mr. J. Gonschorek and Mr. E. Zipfel who conducted the experiments very carefully. The financial support for this work by the U. S. ARL via the European Research Office is gratefully acknowledged.

\section{References}

[1] Rosenberg, Z., Bless, S. J., Yeshurun, Y., Okajima, K.: Proc. of "IMPACT 87", DGM-Informationsgesellschaft 1988, p. $491 \mathrm{ff}$.

[2] Woolsey, P., Kokidko, D., Mariano, S.: "Alternative Test Methodology for the Ballistic Performance of Armor Ceramics", Proc. 5th TACOM Armor Conf., 1989

[3] Hornemann, U., Rothenhäusler, H., Senf, H., Kalthoff, J. F., Winkler, S.: "Experimental Investigation of Wave and Fracture Propagation in Glass Slabs Loaded by Steel Cylinders at High Impact Velocities", Inst. Phys. Conf. Ser. No. 70, 3rd Conf. Mech. Prop. High Rates of Strain, Oxford, 1984

[4] Senf, H., Rothenhäusler, H.: "Crack Behaviour and Dynamic Response of Alumina Under Impact Loading", Shock-Wave and High-Strain-Rate Phenomena in Materials, Marc A. Meyers, Lawrence E. Murr, Karl. P. Staudhammer, MARCEL DEKKER, Inc., 1992

[5] Senf, H., Straßburger, E., Rothenhäusler, H.: "Stress Wave Induced Damage and Fracture in Impacted Glasses", Proc. 4th DYMAT Conference, Oxford, 1994

[6] Straßburger, E., Senf, H., Rothenhäusler, H.: "Stoßwelleninduzierte Risse und Zerstörungen in Gläsern", Fraunhofer-Institut für Kurzzeitdynamik, Weil am Rhein, EMI-Report 7/93, 1993

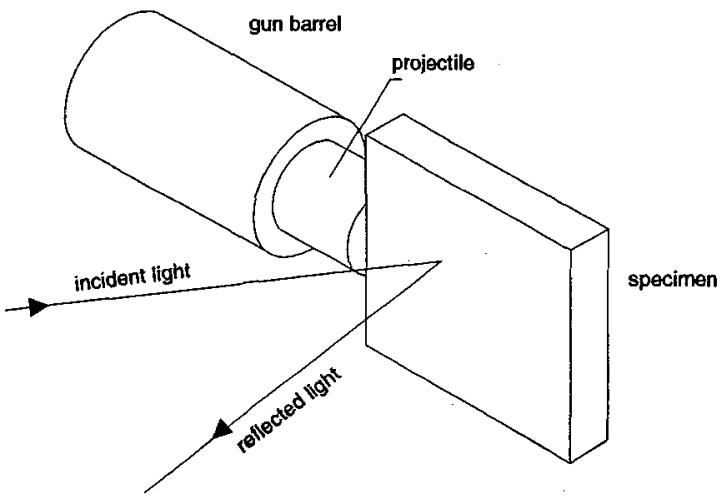

Fig. 1. Experimental set-up 

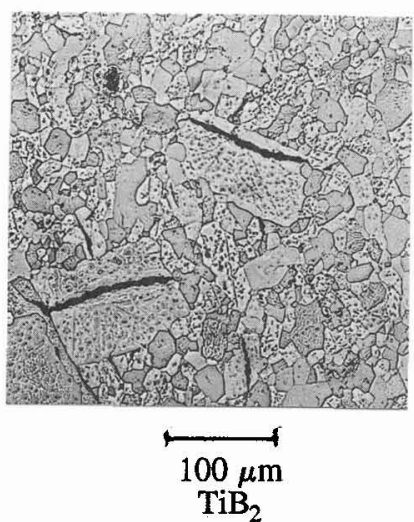

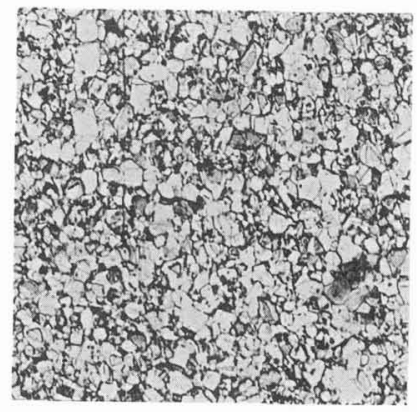

$\underset{\mathrm{SiC}}{20 \mu \mathrm{m}}$

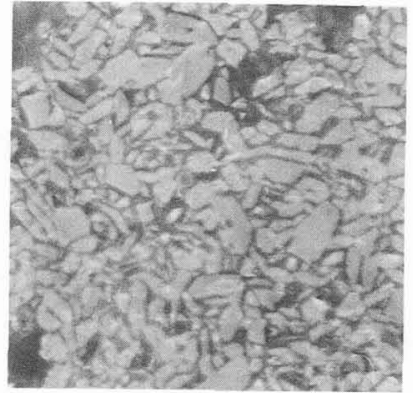

$\stackrel{\overrightarrow{20 \mu \mathrm{m}}}{\longrightarrow}$

Fig. 2. Micrographs of the different ceramics in the initial state
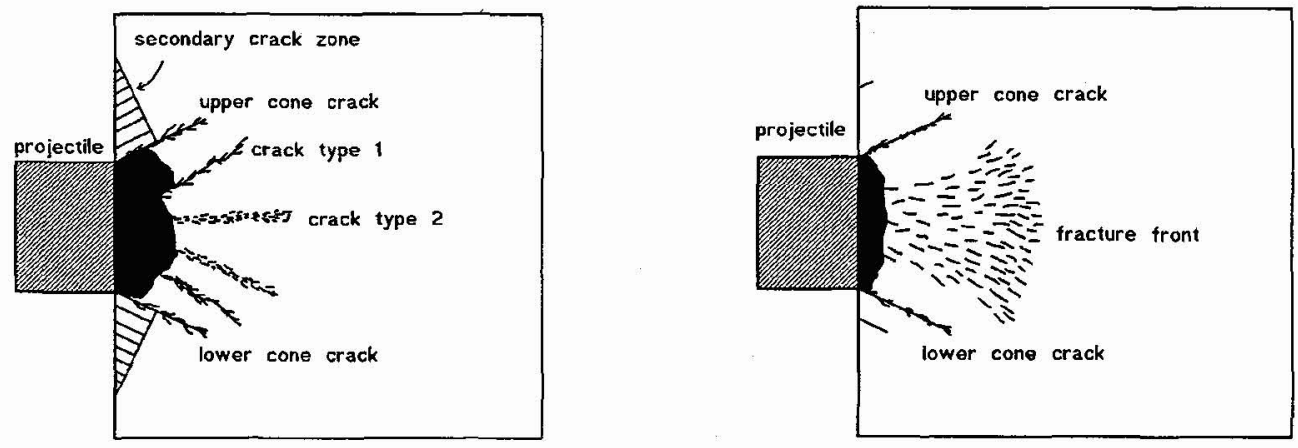

Fig. 3. Schematic representation of the observed fracture types with $\mathrm{SiC}$ and $\mathrm{Al}_{2} \mathrm{O}_{3}$ (a), and $\mathrm{TiB}_{2}$ (b)

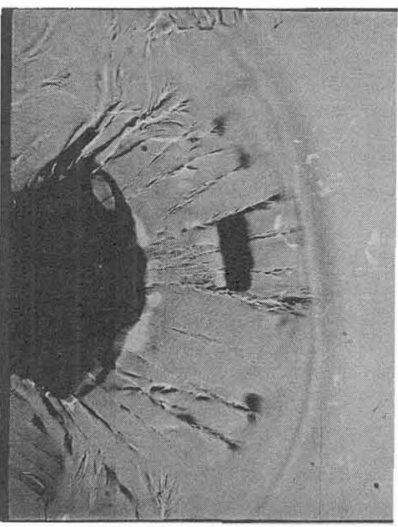

Fig. $4 a$

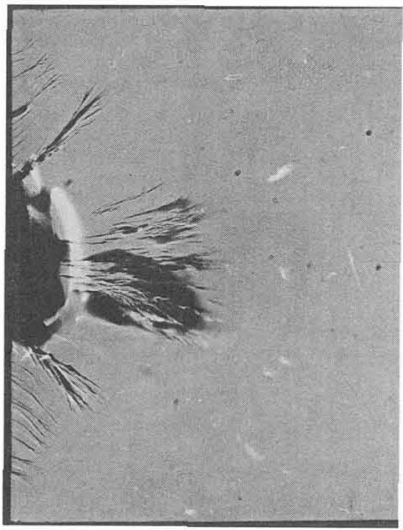

Fig. 4b

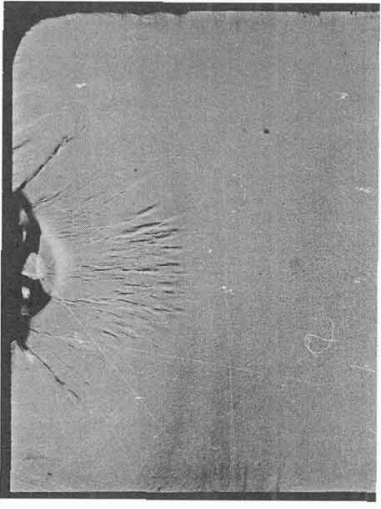

Fig. 5

Fig. 4. $\mathrm{SiC}$ a) $\mathrm{v}_{\mathrm{P}}=150 \mathrm{~m} / \mathrm{s}, \mathrm{t}=10.5 \mu \mathrm{s}$, b) $\mathrm{v}_{\mathrm{P}}=185 \mathrm{~m} / \mathrm{s}, \mathrm{t}=5 \mu \mathrm{s} \quad$ Fig. 5 . TiB $\mathrm{v}_{\mathrm{P}}=85 \mathrm{~m} / \mathrm{s}, \mathrm{t}=4 \mu \mathrm{s}$ 


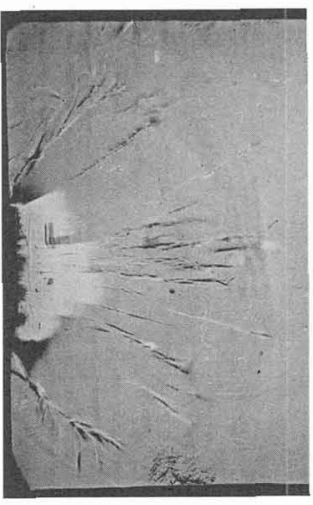

Fig. 6

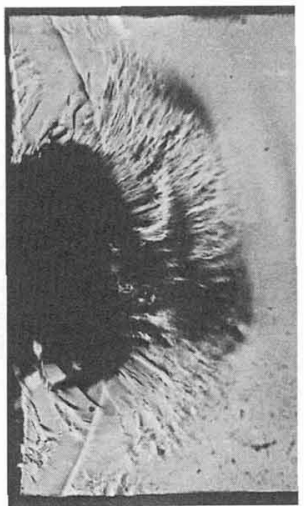

Fig. 7a

Fig. 6. $\mathrm{Al}_{2} \mathrm{O}_{3}, \mathrm{v}_{\mathrm{p}}=85 \mathrm{~m} / \mathrm{s}, \mathrm{t}=9.8 \mu \mathrm{s}$ Fig. 7b. $\mathrm{TiB}_{2}, \mathrm{v}_{\mathrm{P}}=560 \mathrm{~m} / \mathrm{s}, \mathrm{t}=4.7 \mu \mathrm{s}$

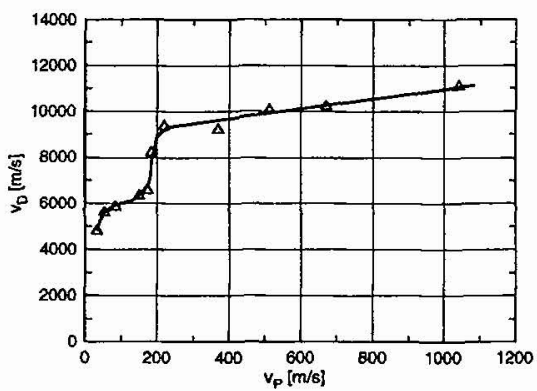

Fig. 9a

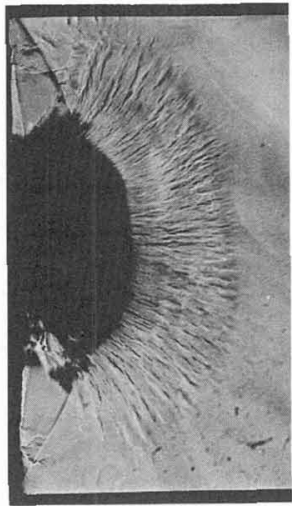

Fig. $7 b$

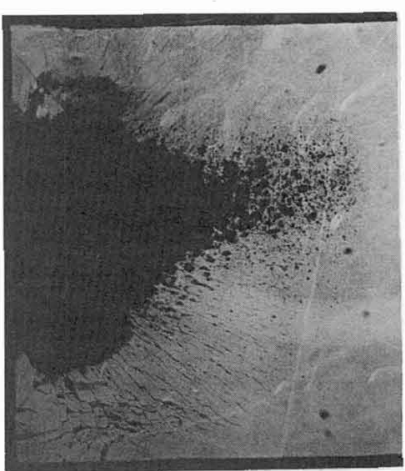

Fig. 8

Fig. 7a. $\mathrm{SiC}, \mathrm{v}_{\mathrm{P}}=513 \mathrm{~m} / \mathrm{s}, \mathrm{t}=4.7 \mu \mathrm{s}$

Fig. 8. $\mathrm{TiB}_{2}, \mathrm{v}_{\mathrm{P}}=784 \mathrm{~m} / \mathrm{s}, \mathrm{t}=6.2 \mu \mathrm{s}$

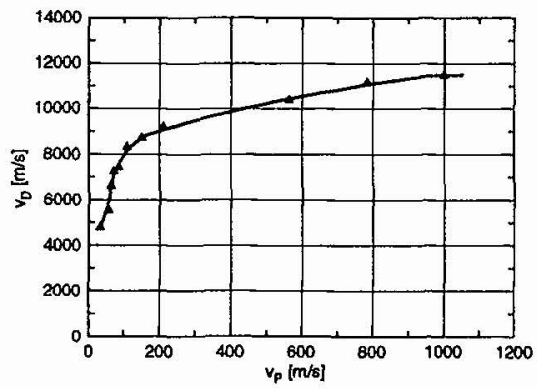

Fig. 9b

Fig. 9. Damage velocity versus impact velocity for $\mathrm{SiC}$ (a), $\mathrm{TiB}_{2}$ (b) and $\mathrm{Al}_{2} \mathrm{O}_{3}$ (c)

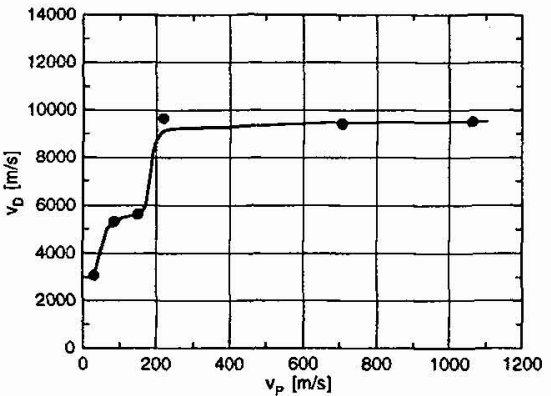

Fig. 9c

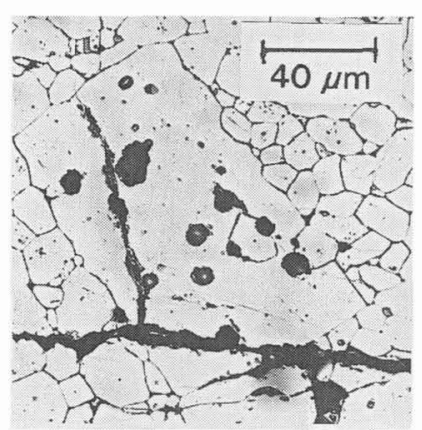

Fig. 10a

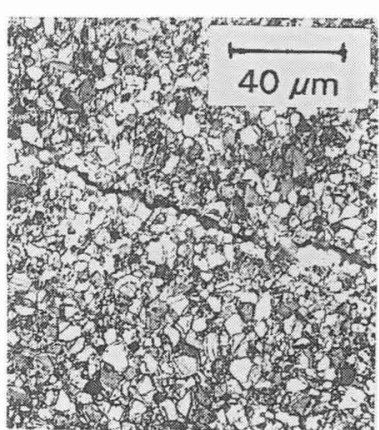

Fig. 10b

Fig. 10. Micrographs of impacted ceramics: a) $\mathrm{TiB}_{2}, \mathrm{v}_{\mathrm{P}}=784 \mathrm{~m} / \mathrm{s}$, b) $\mathrm{SiC}, \mathrm{v}_{\mathrm{P}}=1040 \mathrm{~m} / \mathrm{s}$ 